\title{
Effect of pasture type, phosphorus levels and phosphate solubilizing bacteria on forage productivity under agroforestry system in semi-arid regions
}

\section{SC Sharma, RC Balai \& A Sahoo}

Journal of Agriculture and Ecology

\section{Journal of Agriculture} and Ecology

ISSN: 2456-9410

Volume: 5

Journal of Agriculture and Ecology (2018) 5: 42-49 http://doi.org/10.53911/JAE.2018.5104 


\title{
Effect of pasture type, phosphorus levels and phosphate solubilizing bacteria on forage productivity under agroforestry system in semi-arid regions
}

\author{
SC Sharma $\varnothing$, RC Balai \& A Sahoo
}

Central Sheep \& Wool Research Institute, Avikanagar

Rajasthan- 304501

\section{Corresponding author: SC Sharma, E-mail: $\underline{\text { drscs63@gmail.com }}$}

\begin{tabular}{l}
\hline Article Info \\
\hline Article history \\
Received: 21 April 2018 \\
Accepted: 25 May 2018 \\
Available online: 15 June \\
2018
\end{tabular}

Key Words: Lablab bean, Cenchrus, Phosphorus, pasture, PSB.

\begin{abstract}
A field experiment was conducted to evaluate the effects of pasture type, phosphorus levels and phosphate solubilizing bacteria on forage biomass and quality under agroforestry system in semi-arid conditions during kharif seasons. The result revealed that dry matter accumulation of lablab bean at 60 DAS, crop growth rate (CGR) from 30 to 45 DAS, dry fodder yield (DFY) of lablab bean and total biomass production were recorded significantly higher when lablab bean was sown with cenchrus grass in alternate paired rows, however, protein yield was estimated to be at par among types of pasture. Growth parameters of lablab bean viz. fresh and dry weight per plant at 60 DAS, CGR (30-45 DAS), number and dry weight of nodules per plant at 45 DAS and quality parameters viz. leaf and stem Ncontent, dry fodder yield of lablab bean, total biomass, average $\mathrm{CP}$ content and protein yield increased significantly with increasing levels of phosphorus from 20 to $60 \mathrm{Kg} \mathrm{P}_{2} \mathrm{O}_{5} /$ ha. Positive and significant correlation between total protein yield and $\mathrm{CP}$ content $\left(\mathrm{r}=0.53^{*}\right)$, and biomass production $(\mathrm{r}=0.64 * *)$ was observed. Total biomass production was significantly increased to extent of 9.09 per cent due to PSB inoculation and estimated protein yield was observed to be higher by 10.42 per cent with PSB inoculation as compared to without inoculation.
\end{abstract}

Copyright (02018 Sharma et al., This is an open access article published under the terms of the Creative Commons Attribution License, which permits unrestricted use, distribution, and reproduction in any medium, provided the original work is properly cited.

Preferred citation: Sharma SC, Balai RC \& Sahoo A. 2018. Effect of pasture type, phosphorus levels and phosphate solubilizing bacteria on forage productivity under agroforestry system in semi-arid regions. Journal of Agriculture and Ecology, 5: 42-49; http://doi.org/10.53911/JAE.2018.5104.

\section{Introduction}

Cereals mainly grasses are wides pread used in animal nutrition due to their high dry matte production and low cost (GhanbariBonjar 2000). Cereal-based forage has potential to supply large amount of energy for animals, however, contain low protein and, thus low forage quality. Since, adequate animal nutrition is essential for high rates of gain, efficient reproduction and adequate profits. It is essential to provide animals 
especially ruminants with protein supplements when forage quality is low. Legumes are good source of protein and can be used to compensate cereal protein shortage (Gebrehiwot et al. 1996). The protein content of legumes is typically much higher than that of grasses and legumes fibre tends to digest faster than grass fibre, allowing the ruminants for higher intake. Lablab purpureus (Linn) synonyms Dolichos lablab L. ex. Sweet, is a suitable forage legume for semi-arid regions that can be used in pasture as mixed crop or can be fed as supplement to animal on poor quality diets during dry season (Amole et al., 2013). Lablab bean contains an average of 17 $\%$ protein, $46 \% \mathrm{NDF}, 41 \% \mathrm{ADF}$ and an average dry matter digestibility of $58 \%$ (Murphy \& Colucci 1999). Such traits make lablab bean a suitable fodder crop for semiarid areas. However, phosphorus deficiency often limits establishment and persistence of legumes (Hague et al. 2008), since, it is a nutrient that is necessary for both plant growth and rhizobial activities in nodulation and $\mathrm{N}_{2}$ fixation. Microbial inoculation i.e. phosphate solubilizing bacteria (PSB) increases nodulation, nodule dry weight, $\mathrm{N}$ and $\mathrm{P}$ content in shoot, and fresh and dry fodder (Hassan \& Abdelgani 2009). Keeping above in view, present investigation was carried out to assess the effects of pasture type, phosphorus levels and PSB inoculation on forage biomass and protein yield.

\section{Materials and Methods}

A field experiment was carried out during kharif seasons of 2011 and 2012 at research farm, Central Sheep and Wool Research Institute, Avikanagar $\left(26^{\circ} 18^{\prime} \mathrm{N}\right.$ \& $75^{\circ} 25^{\prime} \mathrm{E}$ in semi- arid conditions. The soil was sandy loam with $\mathrm{pH} 7.6$ having low organic carbon $(0.31 \%)$, available $\mathrm{N}(125.3 \mathrm{~kg} / \mathrm{ha})$, available $\mathrm{P}(8.14 \mathrm{~kg} / \mathrm{ha})$, and available $\mathrm{K}$ $(255.9 \mathrm{~kg} / \mathrm{ha})$. The amount of total rainfall received during the investigation was $674 \mathrm{~mm}$ and $600 \mathrm{~mm}$ in 2011 and 2012, respectively. The experiment was laid out in randomized block design with four replications. The treatments comprised of three forage crop/crop combinations i.e. sole lablab bean (Lablab purpureus Linn.), Lablab bean and cenchrus grass (Cenchrus setigerus, Vahl. ) in 50/50 proportion, and lablab bean and cenchrus grass in alternate paired row, three phosphorus levels viz. 20, 40 and $60 \mathrm{Kg}$ $\mathrm{P}_{2} \mathrm{O}_{5} /$ ha, and with and without phosphate solubilizing bacteria (PSB) seed inoculation. CAZRI- 76 variety of Cenchrus setigerus and JPL-4 variety of Lablab purpureus were used for the study. At sowing $25 \mathrm{~kg} \mathrm{~N} / \mathrm{ha}$ was applied and rest of the required $\mathrm{N}$ was applied through foliar application in cenchrus. These forage crops were taken in already established 6 years old ardu (Ailanthus excelsa) plantation in the configuration of $10 \times 5$ sq. meter. The periodic observations on growth and yield attributes were recorded to assess their impacts on quality and biomass production/ha. Crop Growth Rate (CGR) was calculated from dry weight data using the usual formulae (Watson, 1952). Leaf-N and Stem-N content was estimated using method of Lindner (1994). Crude protein (CP) is calculated by measuring the nitrogen concentration and multiplying by 6.25 (Boisen \& Eggum 1987). 


\section{Results and Discussion}

\section{Pasture Type}

Dry matter accumulation of lablab bean at $60 \mathrm{DAS}$, crop growth rate (CGR) from 30 to 45 DAS, dry fodder yield (DFY) of lablab bean and total biomass production significantly influenced by type of pasture. The mentioned characters were recorded maximum when lablab bean sown with cenchrus grass in alternate paired rows, which were observed to be significantly higher to that of sole lablab bean pasture and lablab bean: grass pasture in 50/50 proportion. Other growth parameters viz. fresh weight per plant at 60 DAS, nodule number and weight, leaf : stem ratio and quality parameters viz. leaf-N, stem-N and average crude protein $(\mathrm{CP})$ were not remarkably differ, however, these characters were also higher in lablab bean : cenchrus grass alternate paired row treatment. The marked increase in dry matter accumulation DMA per plant and CGR (30-45 DAS) of lablab bean might be attributed to wider space between paired rows of lablab bean and differential requirements of interspaced grass led to reduce competition for light, space, nutrients and moisture resulted in to better growth of lablab bean. Patil et al. (1995) also reported higher DMA at wider spaced lablab bean.
Significantly higher DMA per plant at 60 DAS and CGR (30-45 DAS) contributed to higher dry fodder yield of lablab bean when lablab bean: cenchrus sown in alternate paired rows. Hence, total biomass yield of mixed pasture in the said pattern of cropping was maximum and significantly higher to sole lablab bean pasture and lablab bean: cenchrus in $50 / 50$ portion. Sengul (2003) also opined that legume mixed pasture gave higher dry matter yield than single crop. Average crude protein content in lablab bean and cenchrus were not remarkably differing during pasture type, however, it was higher in lablab bean: grass alternate paired rows. Though, biomass yield was significantly higher in this treatment, but protein yield was estimated to be at par among sole lablab bean pasture, lablab bean: grass either in 50/50 portion or in alternate paired rows. This could be attributed to lower $\mathrm{CP}$ content of cenchrus grass that lower down the protein yield in mixed pastures but not to the level of significance. Hence, higher biomass can be harvested from mixed pasture of lablab bean: cenchrus in alternate paired row without considerably affecting the quality i.e. protein yield. It is evident from positive and strong correlation with DFY of lablab bean $0.53^{*}$ and 0.39 , respectively (Table 1). DMA per clump and 
DFY of cenchrus were also higher in lablab bean: cenchrus alternate paired row treatment.

Table 1. Correlation and regression of various dependent and independent variables in lablab beans

$\begin{array}{ccccc}\text { Dependent variable } & \begin{array}{c}\text { Independent } \\ \text { variable }\end{array} & \begin{array}{c}\text { Correlatio } \\ \mathrm{n} \text { ' } \mathrm{r} \text { ' }\end{array} & \begin{array}{c}\mathrm{t}- \\ \text { calculated }\end{array} & \begin{array}{c}\text { Regression } \\ \text { Equation }\end{array}\end{array}$
$\begin{array}{ll}\text { Dry fodder yield (q/ha) } & \text { DMA/plant at } 60 \\ \text { DAS }\end{array}$

$0.53^{*}$

$2.51 \quad \mathrm{Y}=12.62+0.15 \mathrm{X}$

Dry fodder yield (q/ha) CGR (30-45 DAS)

0.39

1.70

$\mathrm{Y}=12.62+1.62 \mathrm{X}$

CGR (30-45 DAS)

Nodules / plant

$0.66 * *$

$\begin{array}{ll}3.53 & \mathrm{Y}=0.642+0.071 \\ \mathrm{X}\end{array}$

Leaf - N (\%)

Nodules / plant

$0.44^{*}$

1.96

$Y=2.23+0.01 X$

Leaf - N (\%)

Nodule weight (g)

$0.43^{*}$

1.94

$Y=2.23+0.28 X$

Stem - N (\%)

Nodules / plant

$0.46^{*}$

2.07

$Y=1.96+0.01 X$

Stem $-\mathrm{N}(\%)$

Nodule weight (g)

$0.52 *$

2.43

$Y=1.96+0.30 X$

Crude protein (\%)

Nodules / plant

$0.51 *$

2.39

$\mathrm{Y}=13.08+0.08 \mathrm{X}$

Crude protein $(\%)$

Nodule weight (g)

$0.54 * *$

2.58

$Y=13.08+1.82 X$

Total Protein yield (kg/ha)

Crude protein $(\%) \quad 0.53 * \quad 2.51$

Total Protein yield (kg/ha)

Biomass (q/ha)

$0.64 * *$

3.34 


\section{Phosphorus levels}

Different levels of phosphorus application to lablab bean brought about significant variations in growth and yield parameters viz. fresh and dry weight per plant at 60 DAS, CGR (30-45 DAS), number and dry weight of nodules per plant at 45 DAS and quality parameters viz. leaf and stem $\mathrm{N}$ content, dry fodder yield of lablab bean, total biomass, average $\mathrm{CP}$ content and finally protein yield (Table 2). All these parameters were recorded maximum with the application of $60 \mathrm{Kg} \quad \mathrm{P}_{2} \mathrm{O}_{5} / \mathrm{ha}$ and were significantly higher to that recorded with the application of 20 and $40 \mathrm{Kg} \mathrm{P}_{2} \mathrm{O}_{5} / \mathrm{ha}$, except leaf- $\mathrm{N}$ and stem-N content, which were at par with the application of $40 \mathrm{Kg} \mathrm{P}_{2} \mathrm{O}_{5} / \mathrm{ha}$. The observed favorable responses of lablab bean to phosphorus application, most especially in case of root nodules and nodule dry weight could be attributed to the role of phosphorus nutrition in forage growth. Phosphorus in known to be involved in energy transfer processes which synthesize and degrade starch and transport nutrients from the soil through the roots to plant tops and $\mathrm{P}$ also enhances cell division, fat formation, flowering, fruiting, seed formation, development of lateral and fibrous roots. Its availability at higher level of phosphorus application i.e. $60 \mathrm{~kg} \mathrm{P}_{2} \mathrm{O}_{5} / \mathrm{ha}$ might have improved forage quality. The results are in agreement with the findings of Ogedegbe et al. (2011). Increasing level of $P$ application also increased cenchrus dry fodder yield which could be ascribed to increase in dry matter accumulation per clump owing to increase availability, absorption and translocation of nutrient in plants on increased $\mathrm{P}$ application. The results are in conformity with the findings of Ram et al. (2006). Increasing levels of $\mathrm{P}$ also brought about significant improvement in total biomass production, which could be attributed to considerable increase in productivity of both, lablab bean and cenchrus grass irrespective to pasture type. Average crude protein content in lablab bean and total protein yield were also increased significantly due to increased $\mathrm{P}$ application (Table 1). Legumes require high amount of phosphorus for their growth, nodule formation and $\mathrm{N}_{2}$-fixation. Leguminous crops have a high phosphorus utilization rate because of their greater requirement during nodulation (Almeida et al. 2000; Hellsten \& Huss-Danell 2001) and $\mathrm{N}_{2}$-fixation (Sonoboir \& Sarawgi 2000). The observed enhancement in number and dry weight of nodule to increased $\mathrm{P}$ availability at higher levels in soil could resulted in additional fixation of molecular nitrogen leading to an improvement in nitrogen metabolism for lablab bean, thus increased leaf and stem N-contents. The study also affirmed a strong and positive correlation between number and dry weight of nodules and leaf-N and stem $\mathrm{N}$-content of lablab bean (Table 2). The results are in agreements of Naeem et al. (2009). Increased biomass and average CP content of both lablab and cenchrus led to significant increase in protein yield due to increase $\mathrm{P}$ nutrition. The results are substantiated by a strong and positive correlation between total protein yield and CP content $\left(\mathrm{r}=0.53^{*}\right)$, and biomass production $(\mathrm{r}=0.64 * *)$. 
Table 2. Growth parameters, nodule number and weight, leaf: stem ratio, N-content, dry fodder yield of lablab bean and biomass production as affected by pasture type, phosphorus levels and PSB inoculation (on mean basis)

\begin{tabular}{|c|c|c|c|c|c|c|c|c|c|c|c|c|}
\hline Treatments & $\begin{array}{c}\text { FW } \\
\text { /plant } \\
60 \\
\text { DAS } \\
\end{array}$ & $\begin{array}{c}\text { DW } \\
\text { /plant } \\
60 \mathrm{DAS}\end{array}$ & $\begin{array}{c}\text { CGR 30- } \\
45 \text { DAS } \\
\text { (g/m²/day) }\end{array}$ & $\begin{array}{l}\text { Nodules } \\
\text { /plant }\end{array}$ & $\begin{array}{l}\text { Nodule } \\
\text { wt. (g) }\end{array}$ & $\begin{array}{c}\text { Leaf: } \\
\text { Stem ratio }\end{array}$ & $\begin{array}{l}\text { Leaf } \\
\mathrm{N}(\%)\end{array}$ & $\begin{array}{c}\text { Stem N } \\
(\%)\end{array}$ & $\begin{array}{l}\text { DFY } \\
\text { (q/ha) }\end{array}$ & $\begin{array}{c}\text { Biomass } \\
\text { (q/ha) }\end{array}$ & $\begin{array}{l}\text { Av. } \\
\text { CP } \\
(\%)\end{array}$ & $\begin{array}{c}\text { Protein } \\
\text { Yield } \\
(\mathrm{kg} / \mathrm{ha})\end{array}$ \\
\hline \multicolumn{13}{|l|}{ Pasture type } \\
\hline Sole Dolichos & 128.5 & 43.88 & 0.59 & 16.71 & 0.762 & 1.11 & 2.20 & 1.98 & 13.08 & 14.11 & 13.06 & 171.4 \\
\hline $\begin{array}{l}\text { Dolichos }+ \\
\text { Cenchrus 50/50 }\end{array}$ & $\begin{array}{c}130.7 \\
(30.17)\end{array}$ & $\begin{array}{c}44.23 \\
(14.31)\end{array}$ & 0.51 & 16.69 & 0.758 & 1.14 & 2.22 & 1.94 & $\begin{array}{c}12.38 \\
(18.02 \\
)\end{array}$ & 15.73 & $\begin{array}{l}13.00 \\
(8.49)\end{array}$ & 159.0 \\
\hline $\begin{array}{l}\text { Dolichos : } \\
\text { Cenchrus } \\
\text { (Alternate } \\
\text { paired rows) }\end{array}$ & $\begin{array}{c}136.3 \\
(29.73)\end{array}$ & $\begin{array}{c}47.98 \\
(14.35)\end{array}$ & 0.83 & 17.21 & 0.765 & 1.15 & 2.26 & 1.96 & $\begin{array}{c}12.42 \\
(18.52 \\
)\end{array}$ & 16.05 & $\begin{array}{l}13.20 \\
(8.52)\end{array}$ & 163.3 \\
\hline $\mathrm{SEm} \pm$ & 0.92 & 0.194 & 0.011 & 0.075 & 0.0033 & 0.003 & 0.004 & 0.004 & 0.059 & 0.073 & 0.020 & 1.01 \\
\hline $\mathrm{CD}(0.05)$ & NS & 0.46 & 0.03 & NS & NS & NS & NS & NS & 0.14 & 0.17 & NS & NS \\
\hline \multicolumn{13}{|c|}{ Phosphorus levels $\left(\mathrm{Kg} \mathrm{P}_{2} \mathrm{O}_{5} / \mathrm{ha}\right)$} \\
\hline 20 & $\begin{array}{c}119.5 \\
(26.72)\end{array}$ & $\begin{array}{c}43.02 \\
(13.47)\end{array}$ & 0.49 & 14.46 & 0.643 & 1.11 & 2.16 & 1.90 & $\begin{array}{c}11.88 \\
(16.77 \\
)\end{array}$ & 14.27 & $\begin{array}{l}12.69 \\
(7.87)\end{array}$ & 147.5 \\
\hline 40 & $\begin{array}{c}134.7 \\
(30.56)\end{array}$ & $\begin{array}{c}45.40 \\
(14.63)\end{array}$ & 0.68 & 17.15 & 0.781 & 1.15 & 2.25 & 1.99 & $\begin{array}{c}12.67 \\
(18.46 \\
)\end{array}$ & 15.41 & $\begin{array}{l}13.25 \\
(8.68)\end{array}$ & 167.6 \\
\hline 60 & $\begin{array}{c}141.3 \\
(32.56)\end{array}$ & $\begin{array}{c}47.67 \\
(14.91)\end{array}$ & 0.75 & 19.06 & 0.862 & 1.14 & 2.26 & 1.99 & $\begin{array}{c}13.33 \\
(19.58 \\
)\end{array}$ & 16.20 & $\begin{array}{l}13.31 \\
(8.97)\end{array}$ & 178.6 \\
\hline $\mathrm{SEm} \pm$ & 0.92 & 0.194 & 0.011 & 0.075 & 0.0033 & 0.003 & 0.004 & 0.004 & 0.059 & 0.073 & 0.020 & 1.01 \\
\hline $\mathrm{CD}(0.05)$ & 2.2 & 0.46 & 0.03 & 0.18 & 0.008 & NS & 0.01 & 0.01 & 0.14 & 0.17 & 0.05 & 2.4 \\
\hline \multicolumn{13}{|l|}{ PSB inoculation } \\
\hline No inoculation & $\begin{array}{c}121.3 \\
(29.23)\end{array}$ & $\begin{array}{c}43.76 \\
(14.13)\end{array}$ & 0.54 & 15.68 & 0.706 & 1.12 & 2.24 & 1.97 & $\begin{array}{c}12.08 \\
(17.35 \\
)\end{array}$ & 14.63 & $\begin{array}{l}13.15 \\
(8.19)\end{array}$ & 156.4 \\
\hline $\begin{array}{l}\text { Seed } \\
\text { inoculation }\end{array}$ & $\begin{array}{c}142.3 \\
(30.67)\end{array}$ & $\begin{array}{c}46.96 \\
(14.54)\end{array}$ & 0.74 & 18.10 & 0.817 & 1.15 & 2.21 & 1.95 & $\begin{array}{c}13.17 \\
(19.19 \\
)\end{array}$ & 15.96 & $\begin{array}{l}13.02 \\
(8.83)\end{array}$ & 172.7 \\
\hline SEm \pm & 0.68 & 0.136 & 0.07 & 0.50 & 0.0022 & 0.002 & 0.003 & 0.003 & 0.040 & 0.049 & 0.014 & 0.67 \\
\hline $\mathrm{CD}(0.05)$ & 1.6 & 0.32 & 0.02 & 0.12 & 0.005 & NS & NS & NS & 0.09 & 0.12 & NS & 1.6 \\
\hline
\end{tabular}




\section{PSB inoculation}

Considerable increase in lablab bean fresh and dry weight per plant at 60 DAS, CGR (30-45 DAS), number and dry weight of nodules at 45 DAS and dry fodder yield were observed due to PSB seed inoculation in comparison to without inoculation (Table 1). It is a fact that applied phosphorus as inorganic fertilizer is not readily available to plants owing to formation of various complexes with $\mathrm{Al}, \mathrm{Fe}, \mathrm{Ca}$ etc. These complexes are essentially insoluble and cannot be taken up directly by roots. The use of PSB as inoculants increased phosphorus availability to plants and $\mathrm{P}$ uptake and thus enhanced the CGR and dry matter accumulation per plant. The results are in conformity with findings of Khan et al. (2009). Similarly increase in number and dry weight of root nodule might be attributed to better availability of phosphorus as a result of solubilizing action of PSB in comparison to without PSB inoculation. Hassan and Abdelgani (2009) also reported similar results. Dry fodder yield of lablab also increased significantly due to PSB inoculation, which might be ascribed to better crop growth and development of plant as a result of higher $\mathrm{N}_{2}$ - fixation due to increased number and dry weight of nodules. Adequate nutrient supply might have exhibited better source to sink relationship. Hassan \& Abdelgani (2009) are also in agreement with these findings.

Total biomass production was significantly increased to extent of 9.09 per cent due to PSB inoculation, which could be attributed to considerable increased in DFY of lablab bean and cenchrus. Average crude protein content was not affected remarkably by PSB inoculation. However, significant improvement in estimated protein yield was observed with PSB inoculation to the tune of 10.42 per cent. A positive and significant correlation $(\mathrm{r}=0.64 * *)$ was found between protein yield and total biomass production. In conclusion, forage biomass and quality could be considerably increased with the application of $60 \mathrm{~kg} \quad \mathrm{P}_{2} \mathrm{O}_{5}$ /ha and lablab bean seed inoculation with PSB in semi-arid condition under agroforestry irrespective to type of pasture either sole or mixed.

\section{References}

Almeida JPF, Hartwig UA, Frehner M, Nösberger J, Lüscher A. 2000. Evidence that $\mathrm{P}$ deficiency induces feedback regulation of symbiotic $\mathrm{N}_{2}$ fixation in white clover (Trifolium repens L.). Journal of Experimental Botany, 51: $1289-1297$.

Amole TA, Oduguwa BO, Shittu O, Famakinde A, Okwelum N, Ojo VOA, Dele PA, Idowu OJ, Ogunlolu, B \& Adebiyi AO. 2013. Herbage yield and quality of Lablab purpureus during the late dry season in western Nigeria. Slovak Journal of Animal Science, 46 (1): 22-30.

Boisen SE \& Eggum BO. 1987. A critical view on the conversion factor 6.25 from total nitrogen to protein. Acta Agronomica, 37: 299- 304.

Gebrehiwot L, McGrow RL \& Assefu G. 1996. Forage yield and quality profile of three annual legumes in the tropical highlands of Ethiopia. Journal of Agriculture, 73: 83-98.

Ghanbari-Binjar A. 2000. Intercropped wheat (Triticum aestivum) and bean (Vicia 
faba) as a low input forage. $\mathrm{Ph} \mathrm{D}$ thesis, Wye College, University of London.

Hague I, Nnadi LA \& Mohamed Salaleem MA. 2008. Phosphorus management with especial reference to forage legumes in sub-Saharan Africa. Food and Agriculture Organization. http://www.fao.org/wairdocs/ilri/x5488e/ x5488eoa.htm.

Hassan MA \& Abdelgani M E. 2009. Effect of microbial biofertilization on nodulation, nitrogen and phosphorus content and forage yield of lablab bean (Lablab purpureus L.). American-Eurasian Journal of Sustainable Agriculture, 3(4): 829-835.

Hellsten A \& Huss-Danell K. 2001. Interaction effects of nitrogen and phosphorus on nodulation in red clover (Trifolium pratense L.). Acta Agriculturae Scandinavica, 49: 00-0

Khan AA, Jilani G, Akhtar MS, Naqvi SMS \& Rasheed M. 2009. Phosphorus solubilizing bacteria: Occurrence, Mechanisms and their role in crop production. Journal of Agriculture Biological Science, 1 (1): 48-58.

Lindner RC. 1994. Rapid analytical methods for some of the more common inorganic constituents of the plant tissues. Plant Physiology, 19: 76-89

Murphy AM \& Colucci PE. 1999. A tropical forage solution to poor quality ruminants diets: A review of Lablab purpureus. Livestock Research for Rural Development, 11: 2.

Naeem M, Masroor M, Khan A \& Moris JB. 2009. Agrobotanical attributes, nitrogen fixation, enzyme activities and nutraceuticals of hyacinth bean (Lablab purpureus L.): a bio- functional meditional legume. American Journal of Plant Physiology, 4(2): 58-69.

Ogedegbe SA, Ogunlela VB, Odion EC \& Olufajo OO. 2011. Growth and growth attributes of lablab (Lablab purpureus $L$. Sweet) as influenced by phosphorus application cutting height and age of cutting. Research Journal of Agronomy, 5(1): 10-19.

Patil VS, Kale PB, Wankhade RV \& Nagdeve MB. 1995. Effect of fertilizer levels and spacing on growth and green pod yield of dolichos bean var. Konkan Bhushan. Vegetable Science, 22 (1): 9-12.

Ram SN, Kumar S, Roy MM \& Baig MJ. 2006. Effect of legumes and fertility levels on buffel grass (Cenchrus ciliaris) and annona (Annona squamosa) grown under horti-pasture system. Indian Journal of Agronomy, 51 (4): 278-282.

Sengul S. 2003. Performance of some forage grasses or legumes and their mixtures under dry land conditions. European Journal of Agronomy, 19 (3): 401-409.

Sonoboir HL \& Sarawgi SK. 2000. Nutrient uptake, growth and yield of chickpea as influenced by phosphorous, rhizobium and phosphate solubilizing bacteria. Madras Agriculture Journal, 87: 149155.

Watson DJ. 1952. The physiological basis of variation in yield. Advance Agronomy, 4: 101-145. 